\title{
Group Defamation and Individual Actions: A New Look at an Old Rule
}

Defamation law is primarily concerned with the protection of reputation. Good reputation is essential to a sense of human dignity, and is a valuable asset in business as well. ${ }^{1}$ An action for defamation not only vindicates a person's good name ${ }^{2}$ and redresses injury, ${ }^{3}$ but it also deters the publication of defamatory statements. ${ }^{4}$

A member of a defamed group, however, lacks the means to vimdicate his good name and redress his injury. Under current defamation law, a group member has no cause of action against the pubhisher of the defamation unless the group is very small or the defamatory statement applies specifically to the plaintiff. This rule is illogical, unfair, and no longer necessary. This Comment proposes abohishing the rule restricting defamation suits by group members. It argues that group members should be permitted to proceed in accordance with the general standards of defamation law. In decisions handed down during the last twenty years, the United States Supreme Court has reached an accommodation between free expression and protection of reputation that should be followed in cases of group defamation. These decisions also create a sufficient barrier against frivolous claims and windfall recoveries-the concerns that gave rise to the bar against individual actions for group defamation.

Part I sets forth the general rule of group defamation, the justifications for the rule, and the exceptions to it. Part II analyzes the justifications in liglit of recent Supreme Court cases, concluding that the justifications do not support a general rule barring individual actions when a group is defamed. Part III considers the exceptions to the general rule as sources of relief for injured group members, and analyzes other avenues of relief that have been suggested by courts and commentators. Part III concludes that none of these approaches provides adequate rehef from the harsh operation of the general rule. Part IV

1. L. Eldredge, The Law of Defamation \& 2 (1978). See Gertz v. Robert Welch, Inc., 418 U.S. 323, 341 (1974).

2. See Restatement (SECOND) OF TORTS $\$ 623$ note (1976); id. $\$ \S 575,622$.

3. L. EldREDGe, supra note 1 , $\S 3$, at 6 ; Restatement (SECOND) OF TORTS $\$ \S 575,621$, 622,623 note (1976). (1976). 
proposes that an individual group member harmed by group defamation should be required to meet the same standards of proof as any other defamation plaintiff, and presents a framework to guide the application of general defamation law principles to cases of group defamation.

\section{I}

\section{The Group Defamation Rule and its Exceptions}

\section{A. The General Rule}

Individual members of groups that have been defamed generally have no cause of action against the defamer. This rule follows froin the requirement that in order to establish a prima facie case of defamation, the plaintiff must demonstrate that a "reasonable person" could perceive the defendant's statement to be "of and concerning" the plaintiff. Unless the defamation designates the plaintiff so that those reading or hearmg the publication understand that the plaintiff is implicated, the plaintiff's reputation cannot be tannisled. ${ }^{6}$ Where a group is the object of defamation, the "of and concerning" requirement poses special difficulties. As group size increases, courts become skeptical that the defamation could reasonably be understood to refer to any individual group nember. ${ }^{7}$

Additionally, courts have justified the denial of redress to individual members of defamed groups by arguing that group defanations lack the tendency to cause personal harm ${ }^{8}$ - that reasonable persons do not take literally statements defaming groups of people, and understand such statements only as generalizations or exaggerations. ${ }^{9}$ Further, as with any area of defamation law, courts are concerned with the chilling effect defamation suits may liave on free expression. ${ }^{10}$ Finally, courts have expressed the fear that permitting individuals to maintain actions in cases of group defamation would overwlielm the courts with

5. REstatement (SECOND) OF TORTS $\$ 564$ A (1976).

6. See Geisler v. Petrocelli, 616 F.2d 636, 639 (2d Cir. 1980). It is not necessary to prove that the defendant intended his statement to refer to the plaintiff; it is enough that the audience could perceive the plaintiff to be imphicated by the content of the statement or even by extrinsic facts. See infra note 25. However, the loolding in Gertz abohishing liability without fault may mean that it is now unconstitutional to hold a speaker strictly liable for defanation not intended to defame the plaintiff, at least as to a media defendant. R. SACK, LIBEL, SLANDER, AND RELATEd Problems \& II.8.1 (1980).

7. See, e.g., Golden N. Airways, Inc. v. Tanana Publishing Co., 218 F.2d 612 (9th Cir. 1954); Neiman-Marcus v. Lait, 13 F.R.D. 311 (S.D.N.Y. 1952); Noral v. Hearst Publications, Inc., 40 Cal. App. 2d 348, 104 P.2d 860 (1940).

8. See Wilner, The Civil Liability Aspects of Defamation Directed Against a Collectivity, 90 U. PA. L. Rev. 414, 419 (1942).

9. Id; J. SALMOND, TORTS $\S 405$ (9th ed. 1936).

10. See infra text accompanying notes 47-67. 
lawsuits."

The seeds of the general rule were planted in an old English case, King v. Alme and Nott. ${ }^{12}$ In that case, the court stated in dictuin that "where a writing . . . inveighs against mankind in general, or against a particular order of men, as for instance, men of the gown, this is no libel, but it inust descend to particulars and individuals to make it a libel."13 An American case, Sumner v. Buel, ${ }^{14}$ misinterpreted this dictum to mean that no action for libel could lie unless a particular person was specifically mentioned. ${ }^{15}$ Froin Sumner arose the modern rule barring individual actions in group defamation cases. ${ }^{16}$

The modern rule is exemphified by Fowler v. Curtis Publishing Co. ${ }^{17}$ where the defendants published an article portraying Washington, D.C. taxicab drivers as ill-namiered with patrons. Although the plaintiff, a Washington, D.C. taxicab driver, was prepared to offer evidence of his loss of busmess resulting from the defamation, the court refused to hear it, holding that an individual member of a group that has been defamed has no cause of action. ${ }^{18}$

\section{B. Exceptions to the Rule}

\section{The Small Group Exception}

There are two exceptions to the general rule that imdividual members of a defamed group have no cause of action. The first exception allows group members to mamtam individual actions where the defamation refers to every member of a small group, because in such cases, "[t]he words may reasonably be understood to have personal reference and application to any member of [the group], so that he is defamed as an mdividual." 19 Althougli few courts have announced fixed rules defining the number of members a small group may have, ${ }^{20}$ most jurisdic-

11. See, e.g., Michigan United Conservation Clubs v. CBS News, Inc., 485 F. Supp. 893, 900 (W.D. Mich. 1980), affd, 665 F.2d 110 (6th Cir. 1981). See also Reisman, Democracy and Defamation: Control of Group Libel, 42 Colum. L. REv. 727, $771-77$ (1942).

12. 91 Eng. Rep. 790 (1700) (per curiam).

13. Id.

14. 12 Johns. 475 (N.Y. 1815).

15. Id. at $477-78$.

16. See Note, Liability for Defamation of a Group, 34 CoLUM. L. REv. 1322, 1322 \& nn. 5-7 (1934).

17. 182 F.2d 377 (D.C. Cir. 1950).

18. Id. at 378.

19. Neiman-Marcus v. Lait, 13 F.R.D. 311, 315 (S.D.N.Y. 1952); De Witte v. Kearney \& Trecker Corp., 265 Wis. 132, 137-38, 60 N.W.2d 748, 751 (1953) (labor union officials defamed as a group; each of the four individuals in the group had a cause of action); W. PROSSER, HANDBOOK OF THE LAW OF TORTS § 111, at 750 (4th ed. 1971); ResTATEMENT (SECOND) OF TORTS § 564A comment b (1976); Annot., 70 A.L.R.2d 1382, 1389 (1960).

20. For a compilation of the prevailing limitations in various jurisdictions, see LIBEL DEFENSE ResourCe CENTER, 50 STATE SURvey (1982). 
tions permit individual actions where the group members number twenty-five or fewer. ${ }^{21}$

The Restatement (Second) of Torts states that individual members of small groups may proceed even when the defamatory statement refers to only some of them. ${ }^{22}$ Several courts have agreed with this extension of the small group exception. ${ }^{23}$

\section{The Specific Application Exception}

The second exception to the general rule arises when the defamation, though made in group terms, is really a veiled reference to a specific group member. ${ }^{24}$ The rationale for this exception is that the

21. W. Prosser, supra note $19, \S 111$, at 750; Restatement (SECOND) of ToRTs $§ 564 \mathrm{~A}$ comment b (1976).

22. REstatemENT (SECOND) OF ToRTS $\S 564$ A comment c (1976). Where the group is very small, a statement directed at only a few, or even at one of the members may suffice to allow each member to sue. See, e.g., RESTATEMENT OF TORTS $\S 564$ comment c, illustration 2 (1938) (statement that some member of B's household has committed murder defames each member of B's household).

23. For example, in Neiman-Marcus v. Lait, 13 F.R.D. 311 (S.D.N.Y. 1952), individuals within a department store's twenty-five inember inale sales staff inaintained an action agamst an author who had written that "most" of the salesmen were "faggots" and "fairies." Id. at 316; see also Cushinan v. Day, 43 Or. App. 123, 130, 602 P.2d 327, 331-32 (1979) ("When all or a significant portion of a small group are defaned, each individual in the group may be found to have been defamed."). Yet, in Neiman-Marcus the court dismissed an action brought by soine of the store's 382 saleswomen because of the group's size, even though the defendant had written that all of the saleswomen were "call girls." 13 F.R.D. at 316. See also Montgonery Ward \& Co. v. Skinner, 200 Miss. 44, 25 So. 2d 572 (1946) (accusation that "one of you three" stole money defamed each of the three accused). But see Cohen v. Brecher, 20 Misc. 2d 329, 192 N.Y.S.2d 877 (1959) (statement that one of three was a criminal not actionable).

Some courts do not allow actions where the publication includes only a general reference to some members of a small group. See, e.g., Owens v. Clark, 154 Okla. 108, 6 P.2d 755 (1931) (defamatory statements regarding "some" members of Oklahoma Supreme Court did not defame each judge); Annot., 70 A.L.R.2d 1382 (1960); cases cited id. And some courts have kept froun the jury actions brought by inembers of groups with less than twenty-five members. For instance, in Service Parking Corp. v. Washington Times Co., 92 F.2d 502 (D.C. Cir. 1937), the court held that a group of ten to twelve downtown Washington, D.C., parking lot owners was not so small that defamation of the group's busmess practices could cause the group inember plaintiff to be personally defamed. Id. at 503, 506.

At least two courts have refused to be bound by considerations of group size. In Fawcett Publications, lnc. v. Morris, 377 P.2d 42 (Okla. 1962), appeal dismissed, 376 U.S. 513 (1963), a second-string player on a seventy member college football teain sued the defendant for publishing an article accusing the tean's players of using anphetamines during ganes. The Oklahoma Supreme Court concluded that "while there is substantial preccdent from other jurisdictions to the effect that a member of a 'large group' may not recover im an individual action for a libelous publication unless he is referred to personally, we have found no substantial reason why size alone would be conclusive." Id. at 51 (emphasis in original). Instead, because the teain players were so well known and identified in connection with the teain, the court held that the article hbeled every member of the team. $I d$. at 52 . A New York appellate court also recently demonstrated its willimgness to look beyond group size. Brady v. Ottaway Newspapers, Inc., 84 A.D.2d 226, 445 N.Y.S.2d 786 (1981).

24. Marr v. Putnam, 196 Or. 1, 18-20, 246 P.2d 509, 517 (1952) (quoting 33 AM. JUR. Libel \& Slander § 192 (1936)); Note, supra note 16, at 1324. 
individual is injured in such circumstances to the same extent as if the defamation had directly referred to that individual. ${ }^{25}$ Thus, the specific application exception is not really an exception to the rule that members of a defamed group have no legal remedy for their mjuries; rather, it is merely a recognition that one who is individually defamed can sue even if the defamation is disguised as a group slur. ${ }^{26}$

II

\section{CRITIQUe of THE JustificATIONS BEHIND THE GRouP DeFAMATION RULE}

The various justifications for the group defamation rule, though facially attractive, are unpersuasive in light of recent developments im defamation law. This Part argues that general defamation law adequately addresses the concerns raised by courts in group defamation cases. Thus, a special rule for group defamation is unnecessary.

\section{A. The "Of and Concerning" Requirement}

\section{Reference to the Plaintiff}

Courts often refuse to permit individual actions for group defamation, based on the belief that an mdividual plamtiff im suclı cases can-

25. See Marr v. Putnam, 196 Or. 2, 16-20, 246 P.2d 509, 516-18 (1952); cases and commentaries quoted id; RESTATEMENT (SECOND) OF TORTS \$ 564A comment d (1976). The defendant's intent is immaterial in determining to whom the statement applied. "The question "is not who was aimed at, but who was hit." Marr v. Putnam, 196 Or. at 28, 246 P.2d at 521 (quoting Laudati v. Stea, 44 R.I. 303, 306, 117 A. 422,424 (1922)); see supra note 6.

26. For example, in Marr v. Putnam, the Oregon Supreme Court allowed the owners of a radio repair service to proceed against the publisher of a local newspaper article alleging that a certam class of radio repair businesses were stealing their custoiners' radios. The article warned against the sharp practices of "these slickers" who, it claimed, commonly advertised by providing no information about their business other than a phone number for customers to call for free pickup service. Since the plaintiffs were the only radio repairmen in the area who advertised in this manner, the court held that those who read the article would believe it referred specifically to the plaintiffs. 196 Or. at 14-15, 246 P.2d at 515.

In one case worth noting, the Ninth Circuit, applying Oregon law, demonstrated a willingness to employ the specific application exception in an innovative inanner. United Medical Laboratories v. CBS, 404 F.2d 706 (9th Cir. 1968), cert. denied, 394 U.S. 921 (1969), concerned a series of broadcasts and press releases issued by CBS claiming that mail-order inedical laboratories, such as the plaintiff, reaclied inaccurate test results $80 \%$ of the time. The trial court had rendered summary judgment in favor of the defendant due to the large size of the group defamed. In reviewing the judgment, the circuit court commented that the plaimtiff's demonstration that it had lost business after the statements were publislied would have required the issue of specific application to advance beyoud the summary judgment stage, but that other considerations required that the judgment be affirmed. The court thereby indicated that a showing of harm resulting from group defamation might bring a group inember's action within the specific application cxception, even in the absence of evidence that the defamation was directed at any particular group member. No court lias yet applied the exception in this maimer. 
not prove that the defamation was "of and concerning" him. ${ }^{27}$ This hiteral and mechamical application of the "of and concerning" requirement is unsatisfactory for several reasons. First, it is unreahstic to assume that the recipients of publications that defame groups do not construe these publications to refer to the imdividual members who constitute those groups. To deny that false accusations leveled agamst a collection of individuals nay cause its inembers to be shunned, feared, or hated does not coinport with the realities of human behavior. ${ }^{28}$ For instance, during the McCarthy era, accusations that certain organizations were overrun by Communists devastated the careers and personal lives of many group members. ${ }^{29}$ These events demonstrate that group defamation can cause extensive imdividual harn. Thus, commentators almost universally agree that the group defannation rule is irrational. ${ }^{30}$

Second, under the current rule of group defamation, judges dismiss individual actions for group defamation on inotions for summary judgment or dismissal, and on deinurrer. ${ }^{31}$ When judges find that group ineinbers could not possibly be injured by a defamation of their group, they remove from the jury its traditional function in defanation law-determining the actual effect of the publication. Yet, the defanatory nature of a publication should "be ineasured not so inuch by its effect when subjected to the critical analysis of a mind trained in the law, but by the natural and probable effect apon the mind of the aver-

27. E.g., Golden N. Airways v. Tanana Publishing Co., 218 F.2d 612, 620 (9th Cir. 1954); Neiman-Marcus v. Lait, 13 F.R.D. 311 (S.D.N.Y. 1952).

28. The commentators are in agreement that individuals may be harmed through group defamation. See, e.g. , L. ELdREDGE, supra note 1, § 10, at 57; Arkes, Civility and the Restriction of Speech: Rediscovering the Defamation of Groups, 1974 Sup. CT. REv. 281, 292-93; Brown \& Stern, Group Defamation in the U.S.A., 13 CLEv.-MAR. L. REv. 7, 23-29 (1964); Wilner, supra note 8, at 425, 432-33; Note, supra note 16, at 1324.

29. See generally J. Anderson \& W. May, McCarthy: the Man, the Senator, the "IsM" (1952) (discussing McCarthy's slurs of government groups and individuals, and the aura of suspicion, fear, and hatred these accusations created).

30. See, e.g., Reisman, supra note 11 , at 770 ("[W] ing the anxieties or the sadism of his audience, and can count on built-in prejudice, he may increase his credibility as he increases the scope and violence of his hes."); Tanenhaus, Group Libel, 35 CORNELl L.Q. 261, 261 (1950) ("The disparagement of racial and rehgious groups not only hurts the groups as collectivities, and the individual nembers thereof, but adversely affects the stability and welfare of the community itself."); Note, supra note 16, at 1324 ("[E]ven a general derogatory reference to a group [affects] the reputation of every member . . . .").

31. See, e.g., Michigan United Conservation Clubs v. CBS News, Inc., 485 F. Supp. 893 (W.D. Micl. 1980) (summary judgment), aff'd, 665 F.2d 110 (6th Cir. 1981); United Medical Laboratories v. CBS, 258 F. Supp. 735 (D. Or. 1966) (summary judgment), aff'd, 404 F.2d 706 (9th Cir. 1968), cert. denied, 394 U.S. 921 (1969); Neiman-Marcus v. Lait, 13 F.R.D. 311 (S.D.N.Y. 1952) (motion to dismiss); Noral v. Hearst Publications, Inc., 40 Cal. App. 2d 348, 104 P.2d 860 (1940) (affirming grant of general demurrer). See also Service Parking Corp. v. Washington Times Co., 92 F.2d 502 (D.C. Cir. 1937) (affirming directed verdict). 
age reader." ${ }^{32}$ The judge's role is to determine whether, in each case, the publication is capable of a defamatory meaning. ${ }^{33}$ It is then for the jury to evaluate whetlier the plaintiff in the case was defamed. ${ }^{34}$ It is considered an error for the court to deny the jury its role wlien "by any reasonable interpretation the language is susceptible of a defamatory meaning." 35

Third, barring individual actions because of lack of reference to the plaintiff is unsatisfactory because inore concrete ineans exist to prevent unharmed plaintiffs from bringing suit. In Gertz v. Robert Welch, Inc. ${ }^{36}$ the Supreme Court lield that if the plaintiff cannot demonstrate that he has suffered "actual injury" from the defamation, he cannot recover damages. ${ }^{37}$ Tlus, it is unnecessary to dismiss a plaintiff under the abstract rationale that, not being individually referred to, he could not have been defamed, and thereby harmed. As the law of defamation stands after Gertz, if the plaintiff cannot demonstrate that he was harmed, his suit can be dismissed at an early stage. If the plaimtiff was actually harmed, and can prove it, it is unfair and irrational to dismiss his suit simply because he was a nember of a group.

\section{The Constitutional Dimension of the "Of and Concerning" Requirement}

Some commentators have stated that New York Times $v$. Sullivan ${ }^{38}$ elevated the "of and concerning" requirement to a constitutionally mandated barrier against mdividual actions for group defamation. ${ }^{39}$ However, such an imterpretation is unwarranted. As New York Times involved a special fact pattern, it cannot be cited as a general bar against individual actions.

In New York Times, a commissioner of the City of Montgomery, Alabaina instituted a libel suit agamst the newspaper for publishing an

32. MacLeod v. Tribune Publishing Co., 52 Cal. 2d 536, 547, 343 P.2d 36, 44 (1959) (quoting

Bates v. Campbell, 213 Cal. 438, 442, 2 P.2d 383, 385 (1931)).

33. Cameron v. Wernick, 251 Cal. App. 2d 890, 893, 60 Cal. Rptr. 102, 104 (1967).

34. Id. at $895,60 \mathrm{Cal}$. Rptr. at 105.

35. Id. at $893,60 \mathrm{Cal}$. Rptr. at 104.

36. 418 U.S. 323 (1974).

37. See id. at 349 ("It is necessary to restrict defamation plaintiffs who do not prove knowledge of falsity or rcckless disregard for the truth to compensation for actual imjury."). The Court has so far declined to define "actual injury," but has indicated that it is "not limited to out-ofpocket loss" and may imclude impairment of reputation, personal humiliation, and inental anguish. Id. at 350. The rule is to be administered through instructions to the jury and "all awards inust be supported by competent evidence . . . Id .

38. 376 U.S. 254 (1964).

39. See Schuster v. U.S. News \& World Report, lnc., 459 F. Supp. 973 , 978 (D. Minn. 1978), affd, 602 F.2d 850 (8th Cir. 1979); RestaTEMENT (SECOND) OF TORTs § 564 comment g (1976); id. $\S 580 \mathrm{~A}$ comment g; Nelon, Media Defamation in Oklahoma: A Modest Proposal and New Perspective (pt. 2), 34 OKLA. L. REv. 737, 738 (1981). 
editorial advertisement describing alleged mistreatment of blacks by Montgomery police. Although the advertisement referred only to actions taken by "police" and made no mention of individuals, the Alabama Supreme Court found that the "average person" knew that the police were under the direction and control of a single commissioner, ${ }^{40}$ and therefore allowed the plaintiff's suit to proceed.

The United States Supreme Court disagreed with the state court's judgment, arguing that it was "plain that these statements could not reasonably be read as accusing [the plaintiff] of personal involvement in the acts in question." 41 The Court therefore held that the "evidence was constitutionally defective . . . [insofar] as it was incapable of supporting the jury's finding that the allegedly hbelous statements were made 'of and concerning' [the plaintiff]." 42

Taken out of context, the latter passage could be read to elevate the "of and concerning" requirement to a constitutional level, and some authorities have interpreted it in this manner. ${ }^{43}$ However, to extend this holding to erect a constitutional barrier against individual actions for group defamation ignores the setting of the case. New York Times was a case in whieh the Supreme Court was concerned with preserving the right to criticize governınent. It was this concern that lay behind the Court's reluctance to find that the statements contained in the advertisement were "of and concerning" the commissioner:

Raising as it does the possibility that a good-faith critic of government will be penalized for his criticism, the proposition relied on by the Alabaina courts strikes at the very center of the constitutionally protected area of free expression. We hold that such a proposition may not constitutionally be utilized to establish that an otherwise impersonal attack on governmental operations was a libel of an official responsible for those operations. ${ }^{44}$

Thus, the Court's holding was that an innpersonal criticism of government cannot be the basis of an individual action for defamation. ${ }^{45}$ The holding should not be read to bar, as a matter of constitutional law, individual actions for group defamation, even when the group is composed of governinent imdividuals. ${ }^{46}$

40. New York Times v. Sullivan, 273 Ala. 656, 674-75, 144 So. 2d 25, 39 (1962), rev'd, 376 U.S. 254 (1964).

41. 376 U.S. $254,288-89$ (1964).

42. Id. at 288.

43. See Bindrim v. Mitchell, 92 Cal. App. 3d 61, 86, 155 Cal. Rptr. 29, 43 (Files, J., dissenting), cert. denied, 444 U.S. 984 (1979); RESTATEMENT (SECOND) OF TORTS $\$ 564$ comment g (1976); id. §580A comment g.

44. 376 U.S. at 291-92.

45. Accord R. SACK, supra note 6, § I.2.1, at 10; id. § II.8.6, at 123.

46. See Brady v. Ottaway Newspapers, Inc., 84 A.D.2d 226, 445 N.Y.S.2d 786 (1981). In that case, the court held that although the defendant defamed a group of policeinen, constitutional 


\section{B. First Amendment Concerns}

Very early on, courts expressed concern that free public discussion of important matters would be impeded if group members could sue for harm personally suffered as a result of group defamation. ${ }^{47}$ Courts considered it especially important to safeguard the freedom to air openly comments about groups and organizations. ${ }^{48}$ The tension between the free debate concerns and the interest in providimg redress for individual injury was resolved in most group defamation cases im favor of the defendant. ${ }^{49}$

Although free discussion of groups may further public discussion of important issues, the constitutional decisions of the past two decades have dramed this rationale of any vitality it once had. The Supreme Court has developed a complex set of rules in the area of defamation law to protect the right of free speech. Thus, the complete bar against individual actions in group defamation cases is an overbroad and unnecessary solution to the problem of the potential chilling of free expression.

In New York Times v. Sullivan, ${ }^{50}$ the Supreme Court met the concerns about chilled speech straight on. The Court formulated the "actual mahce" standard in order to accommodate both society's interest in public debate and the individual's interest in his reputation. ${ }^{51}$ The Court first emphasized the importance of permitting free debate on issues of public importance. The Court repudiated suggestions it had made in the past that defamatory publications were not protected by the Constitution. ${ }^{52}$ Viewing the defense of truth as insufficient to protect such expression, ${ }^{53}$ the Court concluded that erroneous statements, which it considered inevitable in free debate, "must be protected if the

concerns were not implicated. The defamation, the conrt reasoned, was of a specific group of mdividuals and therefore did not constitute an impersonal attack on government operations. $I d$. at 237 n.4, 445 N.Y.S.2d at 793 n.4.

47. Ryckman v. Delavan, 25 Wend. 186 (N.Y. 1840); Note, Libel and Slander: Right of a Member of a Defamed Group to Recover in a Civil Action, 29 CALIF. L. REv. 83, 84 (1940).

48. Ryckman v. Delavan, 25 Wend. 186, 199-200 (N.Y. 1840). See Brown \& Stern, stupra note 28 , at 21 .

49. E.g., Ryckman v. Delavan, 25 Wend. 186, 198-99 (N.Y. 1840). The court stated:

It is far better for the public welfare that some occasional consequential mjury to an individual, arising from general censure of his profession, his party, or his sect, should go without remedy, than that free discussion on the great questions of politics, or morals, or faith, should be checked by the dread of embittered and boundless litigation. Id. at 199 .

50. 376 U.S. 254 (1964).

51. Id. at 279-80. The Supreme Court has not yet decided whether the actual inalice standard applies to nonmedia defendants.

52. See, e.g., Roth v. United States, 354 U.S. 476, 482-83 (1957); Beauharnais v. Illimois, 343 U.S. 250, 266 (1952). See generally L. Eldredge, supra note 1, \$\$ 49-50; New York Tiines v. Sullivan, 376 U.S. 254, 268 \& n.6 (1964) (discussing the law before New York Times).

53. 376 U.S. at 279. 
freedoms of expression are to have the 'breathing space' that they 'need to survive." "54

However, the Court indicated that free speech was not absolute, and inust be balanced against the interests of the defamed individual. Accordingly, the Court held that plaintiffs who are public officials can recover only if they prove "actual malice." In other words, such plaintiffs must prove with "convincing clarity" that the defendant's statement was made "with knowledge that it was false, or with reckless disregard of whether it was false or not." 55

The Court subsequently extended the same balancing of interests approach to other situations. In Curtis Publishing Co. v. Butts, ${ }^{56}$ the actual malice standard was extended to those cases in which the plaintiff is a "public figure." In Gertz v. Robert Welch, Inc. ${ }^{58}$ the Court indicated that even defamation of private individuals is entitled to constitutional protection. Under Gertz, private plaintiffs may not recover for defamation absent some showing of fault on the part of the defendant, ${ }^{59}$ and are not entitled to punitive damages unless they can prove the defendant acted with actual mahice. ${ }^{60}$ In addition, Gertz held that all plaintiffs-public and private-must show actual mjury in order to recover. ${ }^{61}$

Thus, the Court in New York Times and the later cases required plaintiffs to prove actual injury as well as the defendant's culpability. In imposing these requirements, the Court was balancing the conipeting, important interests in defamation cases. In contrast, the group defamation rule does not attempt to accommodate the competing interests. By barring defamation actions by menibers of large groups, the rule gives no credence to a group member's interest in reputation. Thus, the rule is at variance with the spirit of the recent Suprenie Court cases.

Moreover, in light of the difficulty of neeting the requirenients

54. Id. at 271-72 (quoting NAACP v. Button, 371 U.S. 415,433 (1963)).

55. Id. at 279-80, 285-86. "Public officials" are "those among the hierarchy of government einployees who have, or appear to the public to have, substantial responsibility for or control over the conduct of governmental affairs." Rosenblatt v. Baer, 383 U.S. 75, 85 (1966) (footnote omitted). For a discussion of persons held to be public officials, see R. SACK, supra note 6, § V.2.1.

56. 388 U.S. 130 (1967).

57. "Public figures" include those who "occupy positions of such persuasive power and influence that they are deemed public figures for all purposes," Gertz v. Robert Welch, lnc., 418 U.S. 323, 345 (1974), and those who "have thrust themselves to the forefront of particular public controversies in order to influence the resolution of the issues involved," id. See generally R. SACK, supra note 6, \& V.3.1.

58. 418 U.S. 323 (1974).

59. Id. at 347-48. Once again, however, it is unclear whether the Gertz standard applies to nonmedia defendants, and courts are sphit on the question. See generally R. SACK, supra note 6, $\S \mathrm{V} .9 .4$.

60. 418 U.S. at $349-50$.

61. Id. 
imposed by New York Times and its progeny, there is no need to adhere to a rule barring an entire class of suits in order to protect the quality of public debate. The requirements apply in cases of group defaination, and provide ainple safeguards against the impairnent of free expression. As many commentators have noted, the actual inalice standard, which under the guidelines proposed by this Coinment would be applicable in a large number of individual actions for group defaination, ${ }^{62}$ is difficult to satisfy. ${ }^{63}$ Depending on the standard adopted by a particular jurisdiction, it nay also be hard to establish the requisite element of fault in suits by private persons ${ }^{64}$ Thus, the group defanation rule is unjustifiably stricter than the Constitution requires.

Finally, the Supreine Court has lately accorded increased weight to state interests in striking the balance between state and federal powers. ${ }^{65}$ This trend has extended to defaination law, nnanifesting itself first in Gertz $^{66}$ and again in later decisions, where the Court has recon-

62. See infra notes $116-25$ and accompanying text.

63. See, e.g., R. SACK, supra note 6, at xxv-xxvi; id. §§ 1.3, V.5.1.2, V.2.2-V.3. See also Stone v. Essex County Newspapers, Inc., 367 Mass. 849, 867-68, 330 N.E.2d 161, 173 (1975) (subjective actual malice standard of $N e w$ York Times is conceptually narrower than objective criminal recklessness).

The actual malice standard is particularly difficult to meet because it focuses on subjective factors, see R. SACK, supra note 6, § V.5.1.2, and must be proven with "convincing clarity" rather than by a inere preponderance of the evidence. New York Times v. Sullivan, 376 U.S. 254, 285-86 (1963).

64. Although Gertz held only that states may not impose liability without fault for defamation of private individuals, leaving it to each state to define for itself the appropriate standard of liability in such cases, several states have adopted the actual malice standard (or versions thereof) in defamation actions brought by private plaintiffs, at least where the defamation alleged concerns matters of public or general interest. See, e.g., Gay v. Williams, 486 F. Supp. 12 (D. Alaska 1979). Several other states have adopted a negligence standard, but where a media defendant is involved, soune lave chosen to define that standard in terms of whether the defendant departed from the customary practice in the industry. Peagler v. Phoenix Newspapers, 114 Ariz. 309, 560 P.2d 1216 (1977); Aafco Heating \& Air Conditioning Co. v. Northwest Publications, Inc., 162 Ind. App. 671, 321 N.E.2d 580 (1974), cert. denied, 424 U.S. 913 (1976); Jacron Sales v. Sindorf, 276 Md. 580,350 A.2d 688 (1976). See generally R. SACK, supra note 6, § V.9.

65. Tribe, Unraveling National League of Cities: The New Federalism and Affirmative Rights to Essential Government Services, 90 HARv. L. REv. 1065, 1068-69 \& nn.18-20 (1977) (detailing the recent increase in concern for states' rights evidenced in the Supreme Court and the nation in general).

66. In Gertz, the Supreme Court stated:

The legitimate state interest underlying the law of libel is the compensation of individuals for the harm inflicted on them by defamatory falsehood. We would not lightly require the State to abandon this purpose, for, as MR. JUSTICE STEWART has reminded us, the individual's right to the protection of his own good name

"reflects no more than our basic concept of the essential dignity and worth of every luman being-a concept at the root of any decent system of ordered liberty. The protection of private personality, like the protection of life itself, is left primarily to the individual States under the Ninth and Tenth Amendments. But this does not mean that the right is entitled to any less recognition by this Court as a basic of our constitutional system."

418 U.S. at 341 (quoting Rosenblatt v. Baer, 383 U.S. 75, 92 (1960) (Stewart, J., concurring)). 
firmed the importance of state interests in protecting private reputation. ${ }^{67}$ These recent decisions suggest that the automatic resolution in the defendant's favor of the conflicting constitutional and private interests in group defamation cases may be out of step with the general trend of defamation law, and should therefore be reevaluated.

\section{The Threat of Increased Litigation}

The argument that allowing individual actions for group defamation would overburden the courts needs no lengthy analysis. The courts exist to resolve disputes and to provide redress for the injuries of those who come before them. In addition, courts are practiced at detectimg frivolous claims and either disposing of thein before trial is reached, ${ }^{68}$ or exerting influence to bring about a voluntary pretrial resolution. And even if permitting individual actions would produce a flood of new lawsuits-an unlikely result ${ }^{69}$ - the courts or legislatures could fashion a joinder rule that would require shared issues to be tried together $\mathrm{m}$ all actions arising froin the same instance of defamation. ${ }^{70}$

The threat of increased hitigation argument, like the chilling of expression and the lack of hann arguments, is a deficient justification for the group defamation rule. These justifications do not take into account the fact that Supreme Court precedent from the last twenty years provides a sufficient analytical basis for all defanation actions, mcluding cases of group defamation. Therefore, the group defamation rule should be abandoned, and defained group members should be ac-

67. See, e.g., Wolston v. Reader's Digest Ass'n, Inc., 443 U.S. 157, 164-65 (1979); Hutchinson v. Proxmire, 443 U.S. 111, 133-36 (1979); Herbert v. Lando, 441 U.S. 153, 158-60 (1979). See also Van Alstyne, The First Amendment and the Free Press: A Comment on Some New Trends and Some Old Theories, 9 Horstra L. REV. 1, 9 (1980) ("Lately, free-speech and free-press rights have run into a new mood [m the Supreme Court] - a mood that esteems repute more dearly than speech ....").

68. For instance, courts inay dismiss an action when the plaintiffs allegations demonstrate no cause of action, or grant summary judgment when the defendant has adequately established a defense that defeats the plaintiff's claims, or when the evidence inustered by the plaintiff is legally insufficient to sustain the action. The plaintiff's burden of proof in defamation cases has becoine mcreasingly harder to meet in recent years. See supra notes 50-61 and accompanymg text. As a result, defendants should have hittle difficulty in obtaiming summary judgment in cases where the plaintiffs claim is warrantless.

69. As a practical matter, the difficulty of meetimg the proof requirements in defamation actions (especially those relating to malice, lack of privilege, and special dainages, where required, as well as actual injury) makes it unlikely that a change in the group defamation rules would result in any sigmificant annount of new litigation. Beyond this, individual group members may find it economically advantageous to jom their claims, where they may do so, thus minimizing the additional burden courts would have to bear.

70. At least one other commentator has suggested joinder of claims as a way to alleviate the burdens that inight result from a multiphcity of Iawsuits based on a single mstance of defamation. See Note, supra note 16, at 1328-29. 
corded relief. The next Part analyzes forms of relief that have been suggested by courts and commentators.

\section{III}

\section{Possible Avenues of Relief}

An injured member of a group that has been defamed may pursue various avenues of rehef. He can try to fit imto one of the exceptions to the group defamation rule. If neither of these applies, the courts and literature have suggested other possible avenues: an action by the defamed group itself; criminal prosecution of the defendant; individual suits for equitable relief; and individual pursuit of redress under other causes of action. This Part examines these suggested forms of relief, and concludes that none provides a viable solution for individuals imjured by group defamation.

\section{A. The Exceptions}

As previously noted, the two exceptions to the general rule prohibiting individual actions for group defamation are the small group exception and the specific application exception. The first allows members of small groups to sue individually for personal harms resulting from hibel or slander directed at their group. ${ }^{71}$ The second permits a group nember to sue if the circumstances under which the defamatory statement was made could lead a reasonable person to understand that the statement specifically referred to the plaintiff. ${ }^{72}$

The small group exception suffers from two main inadequacies. First, the limit of group size bears no convincing relationship to the harms against which defamation law protects. Commentators agree that the small group exception is irrational; ${ }^{73}$ yet, only two American courts have ventured to reject group size as a controlling factor. ${ }^{74}$ It may be true in some cases that the "suspicion" cast upon, ${ }^{75}$ and therefore the harm suffered by, individual members of a defamed group decreases as group size increases. However, this does not justify barring all actions by members of groups consisting of more than twenty-five persons. Group size should be a factor in the determination of whether

71. See supra notes 19-23 and accompanying text.

72. See supra notes $24-26$ and accompanying text.

73. See, e.g., L. EldREDGE, supra note 1, § 10, at 55-64; Brown \& Stern, supra note 28, at 435-36; Wilner, supra note 8, at 428-29.

74. Brady v. Ottaway Newspapers, Inc., 84 A.D.2d 226, 445 N.Y.S.2d 786 (1981); Fawcett Publications, Inc. v. Morris, 377 P.2d 42 (Okla. 1962), cert. denied, 376 U.S. 513 (1964). See supra note 23.

75. One commentator suggests that the "mtensity of the suspicion cast upon the plaintiff" should determine whether a statement defamatory of a group can serve as the basis of an action by an individual member. Note, supra note 16 , at 1325 . 
an individual member has been implicated and harmed. ${ }^{76}$ But a strict bar based on any particular group size is arbitrary and unfair. ${ }^{77}$

Second, the exception ignores factors other than size that may affect whether a reasonable person could understand the statement to apply to individual group inembers. For instance, a statement that each prospective member of a certam group is required to commit an act of violence agamst a black person can inflict the same amount of harm on each group member, regardless of whether the group has twenty or two hundred meinbers. This is because the statement implicates and is inclusive of each and every group member. ${ }^{78}$

The specific application exception provides even less relief from the general rule of group defamation than does the small group exception. As noted above, ${ }^{79}$ it is not actually an exception to the general rule; rather it only allows an individual to inamtam an action when the statement, though disguised as a group reference, is reasonably understood to be directed at a particular individual. ${ }^{80}$ Thus, this exception provides no redress to a group member mjured because his group, not he, was defamed.

\section{B. Actions by the Defamed Entity}

Permittimg a defamation suit by the defamed group as an entity ${ }^{81}$ answers several of the problems raised by group defamation cases. For instance, a suit by the defamed entity would not present the "of and concerning" dilemma, since the defamation would literally be of and concerning the plaintiff (the group). This approach would also avoid the multiphicity of lawsuits that courts fear would result if individual actions were permitted, and would avoid the chill that some believe would arise from the specter of multiple suits.

Nonetheless, as an alternative to permitting individual group members to sue and recover for group defamations, group actions have

76. See infra notes $112-15$ and accompanyimg text.

77. Especially irrational is the extension of the exception adopted by some jurisdictions that permit individual gronp members to maintain actions even though the defamation is directed at only part of the group, while still denying members of large groups the opportunity to prove and recover for their individual injuries arising from defamation directed at all the group's members. See supra notes 22-23 and accompanying text.

78. Other factors logically affecting how much an audience might attribute defamation to individual group members include how easily the inembers can be identified as belonging to the group, how well known the individual members are, and how strongly worded the defanation was. See Fawcett Publications, Inc. v. Morris, 377 P.2d 42, $51-52$ (Okla. 1962), cert. denied, 376 U.S. 513 (1964); Note, supra note 16, at 1325-26. See infra notes 112-15 and accompanying text.

79. See supra text accompanying notes $24-26$.

80. See supra note 26 (discussing United Medical Laboratories v. CBS, 404 F.2d 706 (9th Cir. 1968), cert. denied, 394 U.S. 921 (1969)).

81. The commentators who have advocated this alternative include Reisman and Tanenhaus. See Reisman, supra note 11, at 756-57; Tanenhaus, supra note 30, at 265. 
certain shortcoinings. First, not all groups suffering harm from defamation are able to bring actions to recover for such damage. The eapacity of a group to sue for defamation depends on whether the jurisdiction in which it desires to sue recognizes it as an entity capable of bringing an action. ${ }^{82}$ In addition, some groups are unable to bring suit because they are too unorganized or internally divided to take cohesive action. ${ }^{83}$ Second, group actions are inadequate because for a group to sue, the defaination must be of the group as a whole, and not just of a certain subgroup. For example, in Los Angeles Fire \& Police Protective League v. Rogers ${ }^{84}$ the unincorporated association of all members of the Los Angeles Fire and Police Departments did not have standing to sue where the defamation in question concerned only the police officers, not the firefighters. Finally, a group suit would not allow group ineinbers to recover personally for damage done to their $\mathrm{m}$ dividual reputations or for inental distress. By leaving subgroups and individuals witlout a remedy for reputational liarms, the group suit fails to provide a satisfactory solution.

\section{Criminal Prosecution}

A possible solution occasionally pursued in the past is punishment of the defendant under a criminal defamation statute. ${ }^{85}$ However, this possibility raises substantial probleins. First and inost significantly, the courts and critics regard sucli statutes to be of doubtful constitutionality. Although in Beauharnais v. Illinois, ${ }^{86}$ the Supreme Court upheld

82. See RESTATEMENT (SECOND) OF TORTS $\$ 562$ \& comment a (1976). While some jurisdictions permit unincorporated associations to maintain actions, others do not. Moreover, many groups will not even meet the legal definition of an unincoporated association.

"Involuntary" groups appear especially unlikely to be permitted to sue. Involuntary groups are those whose constituents have not knowingly formed a group, and who share no common group name or purpose, but who still constitute a group by virtue of their similar positions, similar jobs, businesses or traits, or participation in similar activities. Such groups would imclude a collection of mdependent parking lot busmesses, see Service Parking Corp. v. Washington Times Co., 92 F.2d 502 (D.C. Cir. 1937), a departınent store's staff of salespeople, see Neiman-Marcus v. Lait, 13 F.R.D. 311 (S.D.N.Y. 1952), and "people who are unable to sell their devalued buildings," see Granger v. Time, Inc., 174 Mont. 42, 44, 568 P.2d 535, 537 (1977).

83. See Reisman, supra note 11 , at 773. Most “involuntary" groups, supra note 82 , probably lack the cohesion collectively to instigate a lawsuit.

84. 7 Cal. App. 3d 419; 86 Cal. Rptr. 623 (1970).

85. See, e.g., Beauharnais v. Illinois, 343 U.S. 250 (1952), affirming a crimimal conviction under an Illinois statute that made it a crime publicly to exhibit or publish any

hithograph, moving picture, play, drama or sketch, which publication or exhibition portrays depravity, criminality, unchastity, or lack of virtue of a class of citizens, of any race, color, creed or religion which .... exposes the citizens . . . to contempt, derision, or obloquy or which is productive of breach of the peace or riots.

Id. at 251 (citing Act of June 29, 1917, § 1, 1917 Ill. Laws 362, 363, repealed by Act of June 30, 1961, § 35-1, 1961 Ill. Laws 1983, 2044). See generally Leavy, Protection from Group and Class Defamation by Extremists, 40 L.A.B. BuLL. 23, 25-27 (1964).

86. 343 U.S. 250 (1952). 
an Illinois criminal statute outlawing the publication of matter defamatory of racial or religious groups, that decision has been questioned. The case was decided by a five-to-four inargm, with strong dissents, ${ }^{87}$ and the Supreme Court has never rehed on it as controlling precedent. In addition, the Supreme Court itself, ${ }^{88}$ and at least three circuit courts $^{89}$ have questioned the validity of the decision.

On a more practical level, criminal defamation laws are virtually nonexistent in modern criminal codes. ${ }^{90}$ But even if such statutes exist and are constitutional, no group hibel is actionable under them unless it presents a "clear and present danger" of causing violence. ${ }^{91}$ It is thus evident that if criminal actions for group defamation can be maintained at all, they will only be permitted under a very limited set of circumstances.

87. Justice Black found the statute to be an unconstitutional censorship of the contents of the defamatory publications. 343 U.S. 267-75 (Black, J., dissenting). Justice Reed said that the statute was uuconstitutioually vague. 343 U.S. at 277-84 (Reed, J., dissenting). Justice Douglas argued that the first aneudment mandates that no restraints be put on free speech. 343 U.S. at 284-87 (Douglas, J., dissenting). Justice Jackson stated that states should have the right to impose group hbel sanctions, provided they allow for a defense of truth, consider privileges, and apply the "clear and present danger" test. 343 U.S. at 287-305 (Jackson, J., dissenting).

88. In Garrison v. Louisiana, 379 U.S. 64 (1964), the Supreme Court found a general criminal hibel statute unconstitutional because it did not contain the constitutional requirement that the libel pose a clear and present danger of causing a breach of the peace. Id at 70 . Justice Brennan's majority opinion quoted from the Model Penal Code's comment disapproving criuninal libel statutes:

It goes without saying that penal sanctions cannot be justified merely by the fact that defamation is evil or damaging to a person in ways that entitle him to maintain a civil suit. Usually we reserve the criminal law for harmful behavior which exceptionally disturbs the community's sense of security. . . . It seems evident that personal calumny falls in neither of these classes in the U.S.A., that it is therefore mappropriate for penal control, and that this probably accounts for the paucity of prosecutions and the near desuetude of private criminal libel legislation in this country. . . .

Id. at 69-70 (quoting MODEL. PeNal Code $\$ 250.7$ comments at 44 (Tent. Draft No. 13, 1961)).

89. In Tollett v. United States, 485 F.2d 1087 (8th Cir. 1973), the Eighth Circuit questioned the validity of statutes such as that at issue in Beauharnais in high of the Supreme Court's decision in Garrison. The court also recognized that the interests served by criminal libel statutcs-“"the public right to tranquility" and "the private right to enjoy integrity of reputation"-do not require criminal libel prosecutions for their protection. Id. at 1095-96. Maintcnance of the peace cannot serve as a justification for criminal punishment when there is no threat of imminent violence, the court noted, and individuals can protect their reputations through civil suits. Id. at 1095 . Similarly, the D.C. Circuit, in Anti-Defamation League of B'nai B'rith v. FCC, 403 F.2d 169 (D.C. Cir. 1968), cert. denied, 394 U.S. 930 (1969), in upholding an FCC decision to renew the license of a radio station that broadcast anti-Semitic inaterial, commented that Beauharnais had been left "more aud more barren" by subsequent first amendment cases. $1 d$. at $174 \mathrm{n} .5$. The Seventh Circuit has more recently questioned the constitutionality of the Beauharnais decision. Collin v. Smith, 578 F.2d 1197, 1204-05 (7th Cir.), cert. denied, 439 U.S. 916 (1978). See also Collin v. Smith, 447 F. Supp. 676, 693-97 (N.D. Ill.) (discussing Beauharnais' limited vitality), aff'd, 578 F.2d 1197 (7th Cir.), cert. denied, 439 U.S. 916 (1978).

90. See Arkes, supra note 28, at 283-84. Only two of these statutes still exist. CONN. GEN. Stat. § 53-37 (West 1960); Mass. ANN. Laws ch. 272, § 98c (Michie/Law. Co-op. 1980).

91. See Garrison v. Louisiana, 379 U.S. 64, 70 (1964). 
Finally, criminal punishment is an incomplete remedy for one harmed by defamation of a group to which he belongs. While a criminal action would deter such defamation as effectively as would a civil action, and might lead to the vindication of the plaimtiff's reputation, no damages may be sought in a criminal action to compensate the plaintiff for the harin to his reputation or for other injuries suffered as a result of the defamation. Furthermore, since criminal actions are controlled by government prosecutors, this remedy does not even afford the group member control over whether an action is instituted against the defendant.

\section{Individual Suits for Equitable Relief}

Another avenue for an injured meinber of a defamed group would be an individual action for equitable rehef, seeking either an injunction, an order compelling retraction, or a declaratory judgment that the defamatory statement was untrue. ${ }^{92}$ While equitable actions of this nature have not often been pursued as remedies for defamation, the American Law Institute has recommended that they be given more serious consideration. ${ }^{93}$ Although such actions might well aid im restoring the reputation of the defamed group meinber, courts unwilling to recognize the harms suffered by individual group members as a sufficient basis for an action for damages would probably be similarly dismclined to recognize them as a basis for equitable action.

Moreover, courts tend to consider equitable relief to be generally unsuitable in defamation actions, beheving the legal remedy both adequate and appropriate. ${ }^{94}$ Additionally, since there is no established practice of brimging declaratory judgment actions for defamation or of seeking orders compelling retraction, it is unclear what rules would apply to such actions, or what difficulties might arise in attemptimg to establish such claims. For instance, although the constitutionality of compelled retractions has apparently never been tested, the potential for conflict between this remedy and free speech primciples is clear. ${ }^{95}$ As for declaratory judgment actions, some jurisdictions deny such re-

92. See RESTATEMENT (SECOND) OF TORTS $\$ 623$ note at 326 (1976).

93. Id.

94. Annot., 47 A.L.R.2d 715, 716-21, 724-25 (1956).

95. See Miami Herald Publishing Co. v. Tornillo, 418 U.S. 241, 254-58 (1974) (containing a broadly worded condemnation of a statute forcing newspapers to publish replies of candidates criticized in editorials). But see R. SACK, supra note 6, § VII.5.2 (pointing out that two justices concurred in Tornillo specifically because the constitutionality of retraction statutes was not addressed and suggesting that the issue may therefore remaim open). But even if coinpelled retractions are constitutional, they are an inadequate remedy, for they cannot reacl all those who heard or read the original defamation. Beyond this, retraction has not been treated as a complete substi. tute for damages, but only as a source of nnitigation of larm. See L. EldREDGE, supra note 1, §96 at 544. 
lief even in general defamation actions. ${ }^{96}$ Furthermore, courts are lestitant to grant injunctions in first amendment cases, even in those few settings where they nay be useful, because sucl1 relief may amount to unconstitutional prior restraint. ${ }^{97}$ Finally, these remedies do not allow the individual to receive monetary compensation for injuries actually suffered, and thus do not adequately protect individuals' reputations or deter harmful slurs.

\section{E. Suits by Individuals Alleging Other Causes of Action}

In an atteinpt to circumvent the inadequacies of group defamation law, defamation plaintiffs may seek redress through claims for disparagement of goods or services ${ }^{98}$ or through claims of intentional infliction of einotional distress. But these causes of action also fall short of providing a satisfying solution.

Claims for disparagement of goods or services present significant hurdles for the plaintiff. First, such actions are appropriate only in a commercial context where the derogatory statement was made concerning the quality of a product or sevice offered for sale by the plaintiff and resulted in "special," pecuniary damages sucl as a decline in business or a loss of employment opportunities. ${ }^{99}$ Second, plaintiffs suing under a disparageinent theory bear a particularly lieavy burden of proof, which perhaps explains why this cause of action is rarely pursued even outside the context of group defamation. Not only must the plaintiff prove that the statement published was false and defamatory (as in an action for defamation), but he must also prove (1) lack of privilege; (2) malice; (3) special damages; ${ }^{100}$ (4) that the plaintiff's dainages resulted directly and immediately from the disparagenent; and (5) that the defendant's stateinent played a "inaterial and substantial part" in inducing others not to deal with the plaintiff. ${ }^{101}$ Even when

96. See Restatement (SeCOND) OF ToRTS $\$ 623$ note at 327-28 (1976).

97. Nebraska Press Ass'n v. Stuart, 427 U.S. 539 (1976); New York Times Co. v. United States, 403 U.S. 713 (1971) (per curiam); Near v. Minnesota, 283 U.S. 697 (1931); Annot., 47 A.L.R.2d 715, 726 (1956). But see Leavy, supra note 85, at $27-29$ (arguing that injunctive relief is merited in cases of group defamation).

98. See, e.g., Fowler v. Curtis Publishing Co., 182 F.2d 377 (D.C. Cir. 1950) (action for both libel and disparagement for publication of article depicting taxicab drivers in plaintiff's city of business as ill-mannered, brazen, and conteinptuous of their patrons accompamied by a plotograph of taxicab owned by plaimtiff).

99. See generally R. SACK, supra note 6, § IX.8.3-.4.

100. Id.; REsTATEMENT (SECOND) OF TORTS $\$ \S 623 \mathrm{~A}, 626$ (1976). The special damage requirements are often especially demanding. See, e.g., Fowler v. Curtis Publishing Co., 182 F.2d 377, 379 (D.C Cir. 1950) (plaintiff nust slow "either the loss of particular customers by name, or a general diminution in business [along with] extrinsic facts showing that such special damages were the natural and direct result of the false publication") (quoting Erick Bowman Renedy Co. v. Jensen Salsbery Laboratories, 17 F.2d 255, 261 (8th Cir. 1926)).

101. Kirsch v. Barnes, 153 F. Supp. 260 (N.D. Cal. 1957); Gardner v. West-Col, Inc., 136 Vt. 
these onerous requirements are met, the remedy provided by the disparagement action is imcomplete, as it does not allow recovery for "general," mtangible damages such as emotional distress and harm to personal reputation. ${ }^{102}$

A third problem with disparagement actions is that the "of and concernimg" requirement probably bars suits by individual members of a group whose products have been collectively disparaged. One district court has already imdicated im dicta that it understands the requirement to apply, ${ }^{103}$ and im light of the similarities between defamation and disparagement actions, other courts may be mclined to agree. ${ }^{104}$

One article lias proposed that an action for imtentional mfliction of emotional distress be pursued im group defamation cases. ${ }^{105}$ While this approach may be useful im some cases, its utility is limited to a narrow class of actions. Courts generally impose strict culpability requirements, permitting such actions only where the defendant intentionally or recklessly caused the plaimtiff mental suffering. ${ }^{106}$ Further, the cause of action is normally limited to those cases in which the plamtiff has suffered a severe degree of einotional distress as the result of the defendant's "extreme and dangerous" conduct exceeding all reasonable bounds of decency. ${ }^{107}$ These stringent requirements prevent this cause of action from serving as a significant source of recovery for individual harms arising from group defanation.

\section{IV \\ The Proposed Standard}

This Comment proposes that an individual member of a defamed group of any size be permitted to mamtain an action for his personal mjuries if lie can satisfy the requirements of general defamation law. This Part exammes those requirements and comments on their application im the context of group defamation.

381, 392 A.2d 383 (1978); W. Prosser, supra note 19, § 128 at 920. See Annot., 74 A.L.R.3d 298, 301 (1976).

102. See Restatement (SeCond) OF TORTS $\$ 623$ A (1976).

103. Smith-Victor Corp. v. Sylvania Elec. Prods., lnc., 242 F. Supp. 302,307 (N.D. Ill. 1965). However, to support its proposition, the court in Smith-Vicior cited only National Refining Co. v. Benzo Gas Motor Fuel Co., 20 F.2d 763 (8th Cir.), cert. denied, 275 U.S. 570 (1927), an action for libel.

104. See, e.g., Michigan Uinted Conservation Clubs v. CBS, 485 F. Supp. 893, 904 (W.D. Mich. 1980), affd, $665 \mathrm{~F} .2 \mathrm{~d} 110$ (6th Cir. 1981) (reasoning that the false-light invasion of privacy and the defaination causes of action are sufficiently similar to justify applying the "of and concerning" requirement in the former class of actions).

105. See Brown \& Stern, supra note 28, at 29-32.

106. Restatement (SECOND) OF TORTS $\$ 46$ (1965).

107. Id.; Callaraina v. Associates Discount Corp., 69 Misc. $2 d$ 287, 329 N.Y.S.2d 711, 714 (1972). 


\section{A. The Elements}

\section{The "Of and Concerning" Requirement}

This Comment proposes that a plaintiff be allowed to satisfy the "of and concerning" requireinent by demonstrating that he is a inember of the defained group, and that a reasonable person could understand the defamation to apply to the plaintiff through his affiliation with the group. While expanding the availability of recovery for defamation by eliminating the arbitrary size limit of the current construction of the "of and concerning" requirement, this rule would still allow the courts to protect defendants froin frivolous suits.

The "of and concerning" requirement poses mixed questions of fact and law. To comply with the standards suggested here, judges inust refrain froin precluding an action solely on the basis of group size. Instead, an individual nember's action must be permitted to proceed to the jury if the plaintiff can estabhsh to the satisfaction of the judge ${ }^{108}$ that the plaimtiff was a member of the group defamed, and that a reasonable person could conclude that the defamation apphed to the plaimtiff through his affiliation with the group. ${ }^{109}$ If the plaintiff does not demonstrate his implication or group affiliation, this rule would allow the court to disimss the action or render summary judgment in favor of the defendant. Under the proposal, courts could also disimiss suits where the plaintiff presented insufficient evidence of any other element required to inaintain a defamation action, ${ }^{110}$ or where the statement amounted only to an "impersonal criticism of governinent" not

108. This requirement is already imposed on those plaintiffs who seek to maintain individual actions as members of a small group that has been defained. Blaser v. Krattiger, 99 Or. 392, 395, 195 P. 359, 360 (1921); W. Prosser, supra note 19, § 112, at 750.

109. Defamatiou law already recognizes that an individual may have a cause of action for defamation even if the statement does not obviously disparage him by naine, if it could reasonably be understood to so apply. This is the basis for both the small group and specific apphication exceptions to the general group defamation rule. It is also the basis for the general defamation rule of libel per quod, whereby a person may sue for defamation even where he inust plead extrinsic facts and special damages to establisls that the statement could reasonably be understood as libelous. R. SACK, supra note $6, \S \S$ II.7-II.7.8. The rule proposed here extends and defines the application of these principles in the context of group defamation.

110. To state a cause of action for defamatiou, a plaintiff must allege that the defendant published a false and uuprivileged statement that a reasonable person might consider to refer to the plaimtiff and to have injured his reputation. See L. ELDREDGE, supra note $1, \S 2$ at 3 . But see R. SACK, supra note 6, \& VII.2.3 n.28 (whether presumed damages might still be recovered when actual malice is shown remains unsettled); RESTATEMENT (SECOND) OF TORTs $\$ 621$ caveat at 319 (1976) (declining to take a position on the issue). Additionally, the Supreme Court's decision in Gertz v. Robert Welch, Inc., 418 U.S. 323 (1974), requires all defamation plaintiffs to slow they suffered actual mjury as a result of the defendant's statement, id, at 349 . Beyond this, if the publicatiou is not defamatory ou its face, or does not come within oue of the categories of slander per se, the plaimtiff is also required to plead that he has suffered pecuniary damages. R. SACK, supra note $6, \S \S$ II.7-II.7.8. Fimally, the plaintiff nay be required to allege and prove that the defendant was culpable. Id. $\S \S$ V.1-V.9.4.1. 
actionable under New York Times. ${ }^{111}$

Under the proposed rule, the court would consider several factors to determine whether the plaintiff's action should proceed. These include: (1) the capacity of the defamation to inflict harm; (2) the degree to which the statement "descends to" or implicatcs individual group members - that is, low likely it is that a reasonable person would consider the statement to be true of the individual group members, rather than to be true only of the group generally; ${ }^{112}$ (3) the size and fluidity of the group's meinbership as well as the ease with which group meinbers may be identified; and (4) the persuasiveness of the plaintiff's showing that he has in fact sustained an actual injury to his reputation as a result of the defaination. ${ }^{113}$

If the plaintiff's action survives the court's legal determination under the "of and concerning" and other requirements, and assuming that no otler legal bars have been found to require dismissal or summary judgment of the action, the issue would then be permitted to proceed to the factfinder. The factfinder would consider the evidence and would make a final determination of whether the defamation was reasonably understood to apply to the plaimtiff group mcmber. In so doing, it should be mstructed to consider the same factors ${ }^{14}$ that the court previously considered. ${ }^{115}$

\section{Fault}

The constitutional standards imposed on defamation actions prevent plaintiffs who are public officials or public figures from recoverimg

111. See supra notes $38-46$ and accompanying text.

112. With regard to this consideration, statements that appear on their face to be merely careless overgeneralizations, or that otherwise should not reasonably have been taken literally, or which would normally be discounted by the reasonable reader or listener by virtue of common knowledge or experience may not implicate individual group members enough to be actionable.

113. One early commentator suggested that similar factors determme the "intensity of suspicion" that group defamation casts upon individual group members, and should guide courts in deciding whether the defamation is actionable. See Note, supra note 16, at 1324-26.

114. See supra notes $112-13$ and accompanying text.

115. For example, a jury might be instructed as follows:

With regard to the defendant's publication [imsert publication] which was made concern. img the group of which the plamtiff is a member, you are required to determime whether the statement was also reasouably understood to apply to the plamtiff as a member of the group. In making this determinatiou, you may, but need not, take into consideration such factors as:

(1) Whether, considering the language and content of the statement, an average [reader] [listener] would uuderstand the statement made concerumg the group to also be true with regard to the plaintiff;

(2) The size of the group and the ease with which its members ean be identified;

(3) The intensity of the harmful nature of the statement; and

(4) The likelihood that the statement was actually understood to be true with regard to the plaintiff as reflected by all the evidence that tends to prove or disprove that the plaintiff's reputation was actually harmed by the statement. 
for injuries caused by defamation absent proof that the defendant acted with actual malice. ${ }^{16}$ Private plaintiffs inust also establish that the defendant acted culpably, although the states are free to define for theinselves the standard of fault, as long. as they do not impose strict liability. ${ }^{117}$ Apphied to individual actions for group defaination, these standards provide the necessary safeguards for free and open public debate.

While a group may be composed predominantly of private individuals, the group itself may have attracted intense public interest. In this case, the group has taken on a status distinct from that of its collective unembers and could be considered a "public figure group." Exainples of such groups include the Sierra Club or the National Organization for Woinen. When a private neinber of such a group sues, a question arises as to whether the defendant's conduct should be evaluated under the actual inahice standard, since the defamation was directed toward a "public figure group," or under the standard applicable to private plaintiffs, since the plaintiff is in fact a private individual. ${ }^{118}$ A similar question arises when the defendant has defained a "private group," such as a homeowners' association, yet the individual group member who sues is either a public figure or a public official.

This Comment proposes that the appropriate standard of liability be determined by the status of the group. The Supreme Court created the actual malice standard to encourage vigorous public debate and to protect the rights of those who would speak out on issues of public concern. ${ }^{119}$ When the defamation is directed at a group in the public eye, these considerations come into play, just as they do when the defamation is of an individual in the public eye. Similarly, when the defamation concerns a "private group," society's imterest im the defendant's publication decreases, and the interest of both the group and its meinbers in maintaiming their good reputations increase in importance. ${ }^{120}$

It could be argued that there is a tension between the rule proposed here and the policy considerations relied on by the Supreine Court in Gertz to justify its choice of fault standards in individual defaination cases. Gertz set forth two reasons why the actual malice standard should not be extended to private individuals. First, public officials and public figures have greater access to the inedia than do

116. See supra notes 50-57 and accompanying text.

117. Gertz v. Robert Welch, Inc., 418 U.S. 323, 347 (1974). See supra notes $58-61$ and accompanying text.

118. "Public official groups" are those groups composed of individual public officials. Therefore, individual actions by group members for defamation directed at such a group would not preseut a dilemma as to the standard of conduct to be established.

119. See supra text accompanying notes 50-61.

120. See Gertz v. Robert Welch, Inc., 418 U.S. 323,347 (1974). 
private individuals, and can therefore more easily rebut defamatory statements made about them. ${ }^{121}$ Because private individuals are thus comparatively more vulnerable to injury, the state's interest in protectmg them is greater. ${ }^{122}$ Second, public officials, by "seek[ing] governmental office," and public figures, by affirmatively "thrust[ing] themselves to the forefront of particular public controversies," have taken on a risk of harm from defamatory falsehood. ${ }^{123}$ The private individual, on the other hand, "has relinquished no part of his interest in the protection of his own good name, and consequently he has a more compelling call on the courts for redress of mjury inflicted by defamatory falsehood." 124

In light of this reasoning, the rule suggested here may appear unfair to "private" plaintiffs who are members of public groups. However, two considerations mitigate the apparent injustice. First, the "public figure group" of wlich the plaintiff is a meinber may be willing to devote its group resources to countering the defamation, which would permit the individual plaintiff at least vicarious access to the media to rebut the false charges. Second, private persons who accept memberslip in a "public figure group" have assumed the burdens, as well as the benefits, of voluntary association with a controversial or well-known group. And though "public" plaintiffs who are members of private groups would have a highter burden of proof than if they had been defamed personally, this is not unfair to the defendant. As the defendant defamed a private entity, society's interest in the publication is less than if the defamation had been of a public entity, and thus the actual mahice standard should not apply. ${ }^{125}$

\section{Actual Injury}

The rule set forth in Gertz requiring defamation plaintiffs to demonstrate actual imjury as a prerequisite to recovery, and limiting their damages to such injury (unless actual mahice is proven) ${ }^{126}$ would also apply to actions brought by members of defamed groups. The requirement that a group member demonstrate that he has sustained actual injury as a result of the group defamation would also answer the courts' concern that permitting individual actions would subject those who defame groups to liability for imaginary harms. ${ }^{127}$ Additionally, it is only fair to allow individual group members who can demonstrate

121. Id. at 344 .

122. Id.

123. Id. at 344-45.

124. Id.

125. See supra text accompanying note 120 .

126. See supra notes $36-37$ and accompanying text.

127. See supra text accompanying notes 8-9. 
that the defendant's statement has actually harmed them to proceed just as any other plamtiff.

\section{Causation}

Before Gertz instituted the requirement that defamation plaimtiffs must prove actual injury im order to recover, damage to reputation was presumed from the defamation itself ${ }^{128}$ and the plaintiff was able to recover general damages. However, when the publication was not defamatory on its face, plamtiffs had to prove special damages to recover. A plaimtiff wlio wished to prove special damages liad to demonstrate that such damages proximately resulted from the defamation. ${ }^{129}$ This requirement ensured that the speaker was liable only for harm caused by his conduct, and not for harm that the plaintiff would have suffered even absent the defamation. This causation requirement for special damages has not been mentioned in cases and commentary after Gertz in the context of actual injury.

Under the standards proposed in this Comment, members of groups that have been defamed must not only prove that they suffered actual imjury, but also that sucli mjury was a proximate result of the defamation. This requirement would guard agamst the possibility that those who defame groups would be punished for society's ills. For example, one who publislies an article defamatory of lawyers sliould not be liable to an individual lawyer whose busmess is slow. Unless that lawyer can prove that her loss of business was proximately caused by the defendant's publication, it is most likely that society's general mistrust of lawyers was at the root of the imdividual lawyer's loss of busmess.

\section{B. Damages}

One criticism of allowing individual actions for group defamation stems from the fear that a multiplicity of actions could expose defendants to liability severely out of proportion to the harm the speakers have actually inflicted. The size of recent jury verdicts in defamation actions is a valid concern, and one that has been the subject of much commentary. ${ }^{130}$ The solution to this problem as it pertams to general defamation law is beyond the scope of this Comment, for it must be derived from an overall evaluation by the courts and legislatures of various means to control poorly exercised jury discretion.

Fortunately, however, several approaches exist to minimize the

128. Gertz v. Robert Welch, Inc., 418 U.S. 323, 349 (1974).

129. L. ELDREDGE, supra note $1, \S 32$; W. PROSSER, supra note 19, § 112 at 762.

130. For one commentator's view of this problem, see R. SACK, supra note 6, § VII.2.4. See also id. VII.4.1 app. at 365-68. 
possibility of overcompensation in the context of individual actions for group defamation. First, judges must instruct juries that compensatory damages are limited to actual mjury, as demonstrated by competent evidence. ${ }^{131}$ In this regard, judges should carefully instruct juries to consider all the circumstances of the defamation im determimg damages, ${ }^{132}$ mcluding the extent to which the plaintiff was personally implicated by the statement, the imtensity and harmful nature of the words spoken, and group size. Second, judges should aggressively exercise their power of remittitur to reduce overgenerous verdicts. Fimally, legislatures should examine the possibility of fashioning some form of joinder requirement to further minimize the possiblity that juries will view the mjuries suffered by the individual group member $\mathrm{m}$ isolation, rather than as deriving from defamation of a larger group. By employing these safeguards, an element of supervision and control over jury discretion may be introduced that would minimize the unique habihty risks posed by the recognition of individual actions for group defamation.

\section{CONCLUSION}

Group defamation is an evil that may harm not only the group itself, but also mdividual group members. The standards proposed by this Comment would allow group members to maintam individual actions and to recover for group defamation where they could establish that, under the circumstances, the defamation was reasonably understood to apply to the plamtiff as a member of the group. In addition, these plaintiffs would have to satisfy all the other requirements imposed by general defamation law. While permitting individual actions might appear to pose dangers of unwarranted or excessive habihity and impaired public discussion, careful application of the rules of defamation law developed both at common law and under recent constitutional decisions would adequately control these risks. The interests of speakers would thus be protected, while individual group members would be afforded redress for harms they suffered as a result of group defamation.

Ellyn Tracy Marcus*

131. See supra text accompanying note 126.

132. See supra note 115.

- B.A. 1981, University of California, Berkeley; third-year student, Boalt Hall School of Law, University of California, Berkeley. 